\title{
Paleozoic Laurentia-Gondwana interaction and the origin of the Appalachian-Andean mountain system
}

IAN W.D. DALZIEL University of Texas, Institute for Geophysics, 8701 Mopac Boulevard, Austin, Texas 78759-8397

LUIS H. DALLA SALDA Centro de Investigaciones Geologicas, Universidad Nacional de La Plata, Calle 1 n644, 1900 La Plata, Argentina

LISA M. GAHAGAN University of Texas, Institute for Geophysics, 8701 Mopac Boulevard, Austin, Texas 78759-8397

\section{ABSTRACT}

Laurentia, the rift-bounded Precambrian nucleus of North America, may have broken out from a Neoproterozoic supercontinent between East and West Gondwana. Several lines of evidence suggest that the Appalachian margin of Laurentia subsequently collided with the proto-Andean margin of the amalgamated Gondwana supercontinent in difierent relative positions during early and mid-Paleozoic time, in route to final docking against northwest Africa to complete the assembly of Pangea. Hence the Appalachian and Andean orogens may have originated as a single mountain system. The overall hypothesis retains the same paleomagnetic and paleobiogeographic controls as previous global reconstructions for the Paleozoic Era. Laurentia-Gondwana collisions may help to explain contemporaneous unconformities in the Paleozoic sedimentary cover of the Laurentian, Gondwanan, and Baltic cratons.

\section{INTRODUCTION}

North America was amalgamated with Gondwana in the terminal Alleghanian event of the Appalachian orogenic revolution, thus completing the late Paleozoic assembly of Pangea (Hatcher and others, 1989; Ziegler, 1989). The basic configuration of that supercontinent is well established on the basis of marine geophysical data from the Atlantic Ocean basin (Klitgord and Schouten, 1986). The Precambrian nucleus of the North American continent, Laurentia, is, however, completely surrounded by Neoproterozoic to earliest Paleozoic rift systems (Hoffman, 1989). The revival of earlier suggestions that the Pacific margins of East Antarctica-Australia and Laurentia may have been juxtaposed during Neoproterozoic time (Moores, 1991; Dalziel, 1991) prompts re-evaluation of the widely held assumptions that the ancestral Appalachian margin rifted from northwestern Africa (Wilson, 1966; Hatcher, 1989) and remained opposite that margin, even though widely separated from it at times, until the assembly of Pangea (Scotese and McKerrow, 1990; Torsvik and others, 1990; McKerrow and others, 1991, 1992; Ziegler, 1989).

Recognition of a possible geometric and geologic fit between the Labrador-Greenland promontory of the Laurentian craton and the Arica re-entrant of the Gondwanan craton (Dalziel, 1992a) supports the hypothesis that the North American continent originated between East Gondwana and the cratons that amalgamated to form West Gondwana during Neoproterozoic to earliest Paleozoic time (Dalziel, 1991, 1992a, 1992b; Hoffman, 1991). A Paleozoic path for Laurentia clockwise around the proto-Andean margin of South America in route to its well-defined position within Pangea is compatible with the paleomagnetic data (Dalziel, 1991, his Fig. 2). The lower Paleozoic car- bonate platform of the northwestern Argentine Precordillera has been known for a long time to contain Olenellid trilobites of the Laurentian "Pacific" or "Columban" realm (Borrello, 1971; Jell, 1974; Ross, 1975). It has recently been reinterpreted as a fragment detached from Laurentia following Ordovician collision with Gondwana (Dalla Salda and others, 1992a, 1992b).

Here we discuss, principally from the standpoint of the major cratons, the extent of possible Laurentia-Gondwana tectonic interaction throughout the Paleozoic Era. We conclude that "Wilson cycle"-style opening and closing of ocean basins along the Appalachian and proto-Andean margins may have involved more than one continental collision. Together with the well-documented Paleozoic collisions of Baltica, island arcs, and other terranes with Laurentia and South America, this could help to explain the protracted orogenic history of both the Appalachian and proto-Andean orogens as well as their locations within early Mesozoic Pangea. The possibility that the two orogens initiated as a single complex mountain system may have profound implications for understanding of the tectonic history of the continental interiors, because it could explain long-recognized synchroneity of Paleozoic unconformities on a near-global scale. According to our hypothesis, subduction of the floor of the Pacific Ocean basin beneath the South American sector of Gondwana, and hence the Andean tectonic regime of the present day, could only have started with the diachronous departure of Laurentia from the protoAndean margin in mid- to late Paleozoic times.

\section{NEOPROTEROZOIC RIFTING}

Laurentia is bounded by igneous rocks and sedimentary strata indicating Neoproterozoic to Early Cambrian rifting (Hoffman, 1989). "Back-stripping" of lower Paleozoic miogeoclinal deposits indicates that thermal subsidence along the Cordilleran and Appalachian margins occurred close to the Precambrian-Cambrian boundary, and that the southern boundary of the continent was initiated during Late Cambrian to Early Ordovician time (Bond and others, 1984 and 1991; Ye and Soegaard, 1993). Until recently, it has generally been assumed that the Pacific margin rifted off some cratonic fragment or fragments in Asia (Sears and Price, 1978). The Appalachian margin was mostly taken to have rifted away from Africa (for example, Hatcher, 1989; but see discussion in Rankin and others, 1988), whereas counterparts to the southern margin have been sought in northern South America (Dengo, 1985; Yañez and others, 1991). Canadian and Australian geologists, however, have long been impressed by the similarity of the Neoproterozoic strata along the Pacific margins of their countries (Eisbacher, 1985; Bell and Jefferson, 1987). Moreover, faunal simi-

Geological Society of America Bulletin, v. 106, p. 243-252, 4 figs., 1 table, February 1994. 
larities led some authors to suggest reconstructions placing Laurentia and South America in proximity during the early Paleozoic Era (Bond and others, 1984; Aceñolaza and Durand, 1986; Hartnady, 1986).

Geologic evidence linking the Precambrian cratons of Laurentia and East Antarctic-Australia has been presented by Moores (1991) and Dalziel (1991). Inasmuch as Gondwana had not completely amalgamated until the latest Precambrian or earliest Paleozoic, this juxtaposition prompted the idea that Laurentia may have "broken out" of a Neoproterozoic supercontinent (Dalziel, 1991; Hoffman, 1991). The presence of latest Precambrian (Pan-African/Brazilide) basins within West Gondwana and Phanerozoic modification of the Appalachian and Andean margins obviously discourage attempts at precise Laurentia-South America Neoproterozoic reconstruction. The Labrador-Greenland promontory of the Laurentian craton is, nonetheless, the same general size and shape as the Arica embayment in western South America (Dalziel, 1992a, his Fig. 1; see also our Fig. 1). The Grenville orogen has a possible counterpart in the basement of the ensialic Andean Cordillera, and the enigmatic Precambrian Arequipa massif on the coast of Peru that has yielded $\mathrm{Rb}-\mathrm{Sr}$ and U-Pb zircon ages of ca. 1.9 Ga (Dalmayrac and others, 1977; Shackleton and others, 1979) could be explained as part of the Makkovik-Ketelidian orogen of Labrador and southern Greenland (Hoffman, 1989; Gower and others, 1990). East Gondwana (East Antarctica-Australia-India), the Kalahari craton of Africa, and Laurentia, together with Siberia, Baltica, Amazonia, and the West African craton therefore appear to have formed a major continental mass by $1.0 \mathrm{Ga}$ (approximate end of "Grenvillian" orogenesis), although sutures within Gondwana indicate that ocean basins existed at that time between the East Gondwana-Kalahari, Congo-São Francisco, Amazonian-West African, and Rio de la Plata cratons (Dalziel, 1992a, Fig. 2).

Geochronometric data appear to require suturing of the African and East Gondwana cratons along the Mozambique suture prior to ca. $600 \mathrm{Ma}$. Geometric considerations on a globe of constant radius therefore suggest that the Windermere and Beardmore-Adelaidean rocks of Laurentia and East Antarctica-Australia, respectively, reflect separation of these two continental masses to open the Pacific Ocean basin ca. $750 \mathrm{Ma}$ (Dalziel, 1992b). In this scenario, which is broadly supported by paleomagnetic data (Powell and others, 1993), the latest Neoproterozoic to Early Cambrian rifting along the Cordilleran and Appalachian margins of Laurentia has to reflect a separate tectonic event or events (see also Hoffman, 1992). There may, therefore, have been two supercontinents during the Neoproterozoic, separated by the opening of the Pacific Ocean basin (Dalziel, 1992a). The earlier one, Rodinia of McMenamin and McMenamin (1990), existed from final Grenvillian collisions ca. $1.0 \mathrm{Ga}$ until Adelaidean-Windermere time ca. $750 \mathrm{Ma}$. The other existed for a much shorter period of time from the amalgamation of Gondwana ca. 600 Ma until the separation of Laurentia ca. $540 \mathrm{Ma}$ (see below) and consisted of Laurentia, Gondwana, Baltica, and possibly Siberia. It is the suggested configuration of this younger, and as yet unnamed, supercontinent that is shown in Figure 1. This reconstruction, modified from Dalziel (1992a, Fig. 3) by the inclusion of the Rockall Bank and northern British Isles as part of the Labrador-Greenland promontory of Laurentia, is now supported by new U-Pb data from zircons from the Arequipa massif that yield ages of 1198 and 970 Ma for granulite facies metamorphism of a 1900-Ma-old granitic and metasedimentary protolith (Wasteneys and others, 1993). Thus the rifted counterpart of the northwest Caledonian foreland of the British Isles (Peach and others, 1907) may have been Amazonia (Dalziel, 1993b), and the Neoproterozoic Moinian and Dalradian complexes (A. L. Harris and M.R.W. Johnson, in
Craig, 1991) may be traceable along strike into the Sunsas and Brazilide belts of Peru, Brazil, and Bolivia (Laubacher and Mégard, 1985; Litherland and others, 1989).

The timing of rift-drift transition along the Appalachian margin can be assessed from the ages of rift-related rocks and thermal subsidence studies. Bond and others $(1984,1991)$ concluded that thermal subsidence in eastern North America started at about the beginning of the Cambrian period. Geochronometric data on rift-related igneous rocks (Kamo and others, 1989), stratigraphic studies in western Newfoundland (Williams and Hiscott, 1987), and the lithology and fauna of the Puncoviscana Formation along the western margin of the Amazonian craton (Jezek and others, 1985; Aceñolaza and Durand, 1986) indicate that rift-drift transition took place in latest Precambrian to Early Cambrian time along both the Laurentian margin and the South American margin of the recently amalgamated Gondwana craton.

In the following sections, we present additional reconstructions of the major continents, for the Cambrian Period when Laurentia was isolated, and for times during the Ordovician and Devonian periods when we suggest that it may have collided with Gondwana. Reference is made in the text to critical, and in some cases problematical, aspects of the intervening time intervals during what we envisage as Laurentia's generally clockwise motion around the South American margin to final docking with northwestern Africa to complete Pangea. Rotation paramers are presented in Table 1.

\section{CAMBRIAN TO EARLY ORDOVICIAN IAPETUS}

Stratigraphic and faunal provenance studies both indicate that Laurentia was an isolated continent by the Atdabanian Stage of the Early Cambrian (McKerrow and others, 1992). Early Paleozoic world maps based on paleomagnetism, paleobiogeography, and climatically controlled lithofacies generally show the Iapetus Ocean (Harland and Gayer, 1972) bounded by Laurentia, Bailtica, and present-day northwestern Africa (for example, McKerrow and others, 1991, 1992). These reconstructions do not address, however, the origin of the Appalachian margin of Laurentia south of New England, nor that of the Ouachita embayment. Moreover, they explicitly leave unexplained the presence of the lower Paleozoic carbonate platform in western South America that is stratigraphically (Ramos and others, 1986) and faunally (Borrello, 1971; Ross, 1975; Bordonaro, 1990) virtually indistinguishable from that of the Laurentian craton. An alternative reconstruction, based on the premise that Laurentia could have been located between South America and East Antarctica-Australia in the late Precambrian, appears to meet these shortcomings without violating any of the paleomagnetic, faunal, or climatic data. In Figure 2, Cambrian Iapetus is shown as consisting of two parts. "Baltic" Iapetus is the conventional ocean between Baltica and the Greenland margin of Laurentia, whereas “Gondwanan" Iapetus (Dalziel, 1992b) is an ocean between the central and southern Appalachian margin of Laurentia and the proto-Andean margin of South America. The Tornquist Sea separates Baltica from Gondwana as in the reconstruction of Torsvik and others (1990).

The evidence for the existence of Iapetus is well known. In the Arctic Caledonides, the British Isles, the Canadian Maritimes, and the Carolinas, a complex early Paleozoic orogen, including rocks of oceanic character, separates the Laurentian craton from an opposed continental margin characterized by a different faunal realm of benthic trilobites (Williams, 1964; Wilson, 1966; Bird and Dewey, 1970; Harland and Gayer, 1972; Secor and others, 1983). Less widely known is the fact that an early Paleozoic orogen in southern South America, 


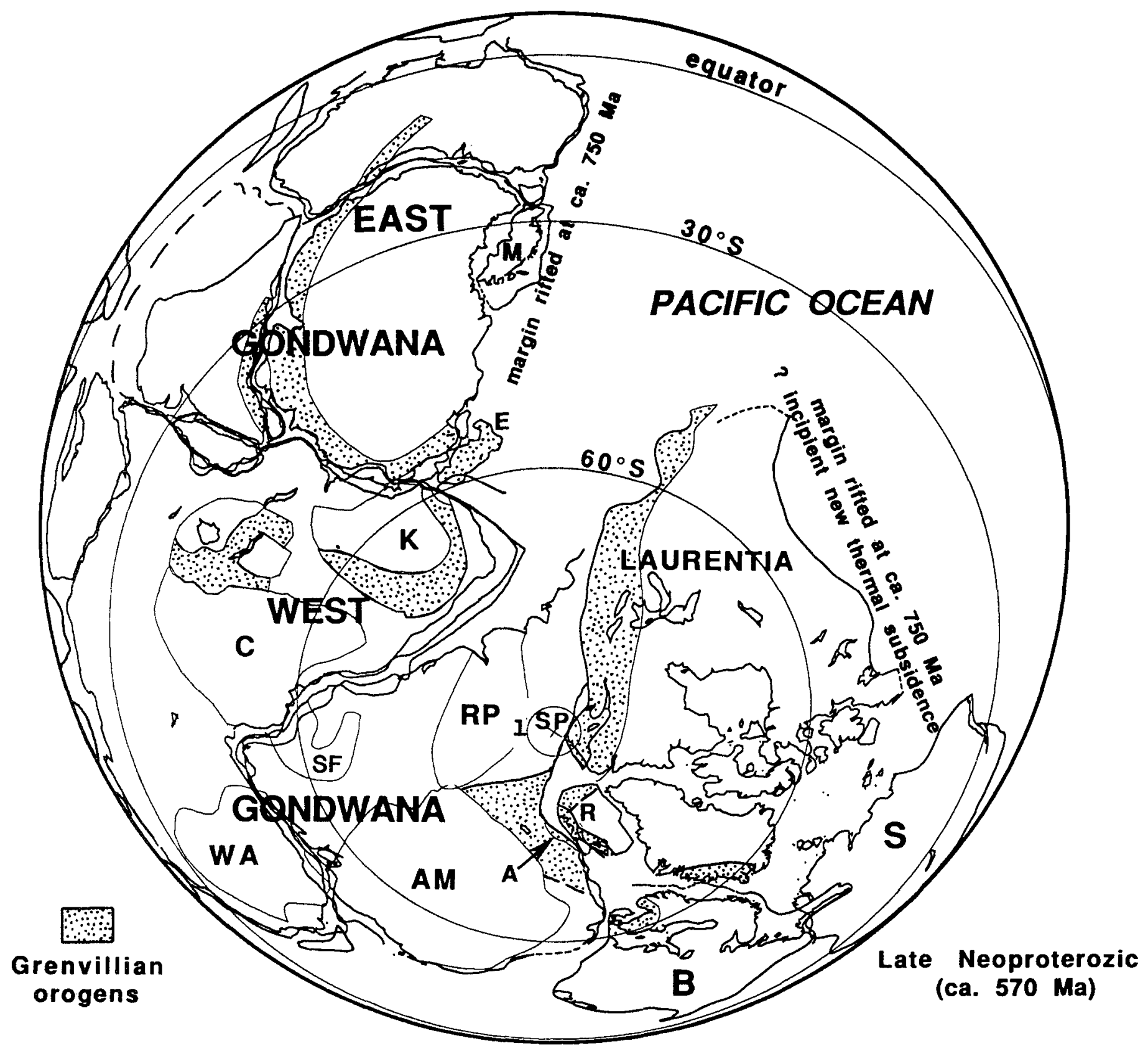

Figure 1. Reconstruction (all projections are orthographic) of the unnamed supercontinent including Laurentia and Gondwana in late Neoproterozoic time (ca. $570 \mathrm{Ma}$ ), following rifting of western Laurentia from East Antarctica-Australia, the opening of the Pacific Ocean basin, and the amalgamation of Gondwana (Dalziel, 1992a, 1992b). Note, however, that some of the PanAfrican/Brazilide basins may not have completely closed by the end of the Precambrian. The Labrador-Greenland promontory of Laurentia (including the Rockall Bank and northern British Isles) and the Arica embayment of the South American craton are used to position those two continents. Gondwana and Laurentia are assembled using the Mesozoic-Cenozoic sea-floor-spreading data (PLATES Project data base compilation, Institute for Geophysics, Univ. Texas at Austin). Baltica is positioned adjacent to Greenland and northwestern South America as advocated by Gower and others (1990). The supercontinent is shown in the reference frame of the paleomagnetic South Pole for Laurentia (SP) determined by Symons and Chiasson (1990) for the Callendar alkaline complex of Ontario dated by the $\mathrm{K}-\mathrm{Ar}$ and $\mathrm{Pb}-\mathrm{Pb}$ methods at ca. $575 \mathrm{Ma}$. The small circle labeled 1 is the circle of confidence at the $95 \%$ level for this pole. Siberia is positioned as suggested by Hofiman (1991), but it may have rifted away from Laurentia by this time (see Heaman and others, 1991).

A, Arequipa massif; AM, Amazonian craton; B, Baltica; C, Congo craton; E, Ellsworth-Whitmore mountains block of Antarctica restored according to Dalziel and Grunow (1992); K, Kalahari craton; M, Marie Byrd Land positioned as in Dalziel (1991); R, Rockall Bank and northern British Isles; RP, Rio de la Plata craton; S, Siberia; SF, São Francisco craton; WA, West African craton. 
TABLE 1. FINITE POLES OF ROTATION

\begin{tabular}{|c|c|c|c|c|}
\hline \multicolumn{5}{|c|}{ Laurentia relative to the Earth's spin axis } \\
\hline $\begin{array}{l}\text { Time } \\
\text { ca. } 370 \\
\text { ca. } 450 \\
\text { ca. } 530 \\
\text { ca. } 570\end{array}$ & $\begin{array}{c}\text { Latitude } \\
13.1 \\
22.2 \\
22.3 \\
-2.7\end{array}$ & $\begin{array}{c}\text { Longitude } \\
-167.0 \\
-143.9 \\
-145.8 \\
-142.4\end{array}$ & $\begin{array}{l}\text { Angle } \\
-63.84 \\
-81.07 \\
-76.59 \\
-136.63\end{array}$ & \begin{tabular}{l}
\multicolumn{1}{c}{ Reference } \\
Van der Voo, 1993 \\
Van der Voo, 1993 \\
Tanczyk and others, 1987 \\
Symons and Chiasson, 1990
\end{tabular} \\
\hline \multicolumn{5}{|c|}{ South America relative to Laurentia } \\
\hline $\begin{array}{l}\text { Time } \\
370 \\
450 \\
530 \\
570\end{array}$ & $\begin{array}{c}\text { Latitude } \\
15.6 \\
12.4 \\
-8.5 \\
2.3\end{array}$ & $\begin{array}{c}\text { Longitude } \\
-47.5 \\
-55.6 \\
-60.5 \\
-23.6\end{array}$ & $\begin{array}{l}\text { Angle } \\
-64.87 \\
-105.10 \\
-135.17 \\
-99.34\end{array}$ & $\begin{array}{l}\text { Reference } \\
\text { This study } \\
\text { This study } \\
\text { This study } \\
\text { This study }\end{array}$ \\
\hline \multicolumn{5}{|c|}{ Baltica relative to Laurentia } \\
\hline $\begin{array}{l}\text { Time } \\
370 \\
450 \\
530 \\
570\end{array}$ & $\begin{array}{c}\text { Latitude } \\
69.1 \\
63.2 \\
58.8 \\
-68.3\end{array}$ & $\begin{array}{c}\text { Longitude } \\
156.7 \\
-62.2 \\
-52.2 \\
-52.3\end{array}$ & $\begin{array}{l}\text { Angle } \\
-23.64 \\
-88.01 \\
-93.05 \\
22.35\end{array}$ & $\begin{array}{l}\quad \text { Reference } \\
\text { Lawver and others, } 1990 \\
\text { This study } \\
\text { Torsvik and Trench, } 1991 \\
\text { This study }\end{array}$ \\
\hline \multicolumn{5}{|c|}{ Siberia relative to Laurentia } \\
\hline $\begin{array}{l}\text { Time } \\
530 \\
570\end{array}$ & $\begin{array}{c}\text { Latitude } \\
4.0 \\
24.1\end{array}$ & $\begin{array}{c}\text { Longitude } \\
-48.0 \\
17.2\end{array}$ & $\begin{array}{l}\text { Angle } \\
172.65 \\
19.77\end{array}$ & $\begin{array}{l}\text { Reference } \\
\text { This study } \\
\text { This study }\end{array}$ \\
\hline $\begin{array}{l}\text { No } \\
\text { No } \\
\text { So } \\
\text { Ea } \\
\text { We }\end{array}$ & $\begin{array}{l}\text { is in millio } \\
\text { ude is }+ \text {. } \\
\text { ade is -. } \\
\text { ude is }+ \text {. } \\
\text { tude is }- \text {. }\end{array}$ & ears. & & \\
\hline
\end{tabular}

also incorporating rocks of oceanic affinities, lies between the Pacific edge of the Gondwana craton (Amazonian and Rio de la Plata cratons) and the carbonate platform in the Andean Precordillera to the west that has the fauna of Laurentian affinity. According to Bordanero $(1990$, p. 25) $70 \%$ of the trilobite genera in this "restricted carbonate platform facies" of the Cambrian and Lower Ordovician strata is North American, $13 \%$ is cosmopolitan, and the remainder is endemic to the Precordillera. This fauna constitutes the so-called "San Juan province," and the tectonic unit characterized by the carbonate rocks is known as the Pre-Cordilleran terrane that was regarded by Ramos and others (1986) as "distantly allochthonous" to South America, and is usually interpreted as a far-traveled block (Keppie, 1991; McKerrow and others, 1992; Courjault-Radé and others, 1992). It is the Precordilleran terrane that has recently been reinterpreted as part of a more extensive but narrow continental sliver, the Occidentalia terrane, believed to represent the western foreland of a Paleozoic collisional orogen, the Famatinian belt (Dalla Salda and others, 1992a, 1992b).

Following publication of the suggestion that Laurentia could have been attached to East Antarctica-Australia in Neoproterozoic time and adjacent to the South American margin of Gondwana early in the Paleozoic Era, Dalla Salda and others (1992a) postulated that Ordovician deformation, metamorphism, and plutonism in the Famatinian belt, collectively known as the Ocloyic event (Ramos and others, 1986; Mon and Hogn, 1991) resulted from Laurentia-Gondwana collision and was equivalent to the Taconian event of the Appalachians. An extension of this hypothesis has the Famatinian orogen as the southward continuation of the Taconic Appalachians, and the Occidentalia terrane as a fragment of the Laurentian craton that rifted from the Ouachita embayment of North America along the pre-existing Reelfoot-Ouachita trough rift system (here called the "Ouachita embayment fault system") following collision (Dalla Salda and others, 1992b). A critical point is that the basement beneath the CambroOrdovician strata of the Precordillera is not seen. Crystalline rocks comprising the remainder of the Occidentalia terrane have not been extensively dated radiometrically. There are, however, indications of Grenvillian ages in $\mathrm{Rb}-\mathrm{Sr}$ and $\mathrm{K}$-Ar data from these rocks (Dalla Salda and others, 1992a), and Grenvillian ages have been reported for detrital zircons in Devonian sandstone of the Precordillera (Loske, 1992). Moreover, geochemical data recently acquired from xenoliths in Miocene volcanic rocks (including a $\mathrm{Pb}$ isochron and a $\mathrm{U} / \mathrm{Pb}$ zircon age) indicate that the basement of the Precordillera is at least in part Grenvillian (Abbruzzi and others, 1993) and hence compatible with an eastern or southern Laurentia origin for the overlying carbonate platform and Occidentalia as a whole.

Reconstruction of Cambrian Iapetus with the central and southern Appalachian margin of Laurentia opposed to the proto-Andean margin of South America, and with the Occidentalia terrane restored to the Ouachita embayment (Fig. 2), thus appears to offer a solution to the origin of the southern margin of Laurentia and of the Precordilieran of northwest Argentina. It is also compatible with the distribution of carbonate platforms and with the distribution of the trilobite faunas, yet it does not appear to violate any of the well-established geologic relations of the present-day North Atlantic region (McKerrow and others, 1991, 1992). Only the paleomagnetically uncontrolled longitudinal position of Laurentia with respect to Gondwana of more conventional paleogeographic maps for the Cambrian Period need be changed.

There are indications of a Late Cambrian to Early Ordovician age for the initiation of thermal subsidence in the Ouachita embayment, significantly later than along the Appalachian margin (Bond and others, 1984; Ye and Soegaard, 1993). Carbonate sedimentation in both the Ouachita embayment and the Weddell Sea region of the East Antarctic margin was later (mid- to Late Cambrian) than along either the Cordilleran or Appalachian margins of Laurentia (Dalziel, 1991). This suggests that the southern margin of Laurentia may have stayed close to the comparatively high southern latitude $\left(-30^{\circ} S\right)$ southern African/South American end of the Transantarctic margin well into the Cambrian (Fig. 2). Webers and Yochelson (1989) commented on the remarkable similarity between primitive molluscs in the Ellsworth Mountains of Antarctica and those in the cratonic interior of Laurentia (see also Webers and others, 1992). The Ellsworth Mountains are also unusual in that they contain a mixed Laurentian and AustraloSinian Late Cambrian Asaphelaspis Zone trilobite fauna (Shergold and Webers, 1992).

Paleomagnetic data appear to require that Gondwanan Iapetus between Laurentia and Gondwana became of Atlantic proportions during the Cambrian (Fig. 2). Even without regard for paleolongitude, they indicate that plate motions during the Vendian to Early Cambrian were relatively high, but on the same order as some of those recorded by ocean-floor magnetic anomalies during the Mesozoic and Cenozoic (Meert and others, 1993). By the Late Cambrian to earliest Ordovician, the position of Gondwana relative to the South Pole appears to have changed (Van der Voo, 1993; Grunow, 1993), thereby narrowining Gondwanan Iapetus (Dalziel, 1991, 1992b; Dalla Salda and others, 1992b) by subduction of the Cambrian oceanic lithosphere beneath cratonic South America (Dalla Salda and others, 1991b; Fig. 2).

\section{TACONIAN COLLISION, ACADIAN TRANSPRESSION, AND ALLEGHANIAN SUTURING}

To a first approximation, the early Paleozoic Taconic and Ocloyic belts appear to have a remarkably similar structure and his- 


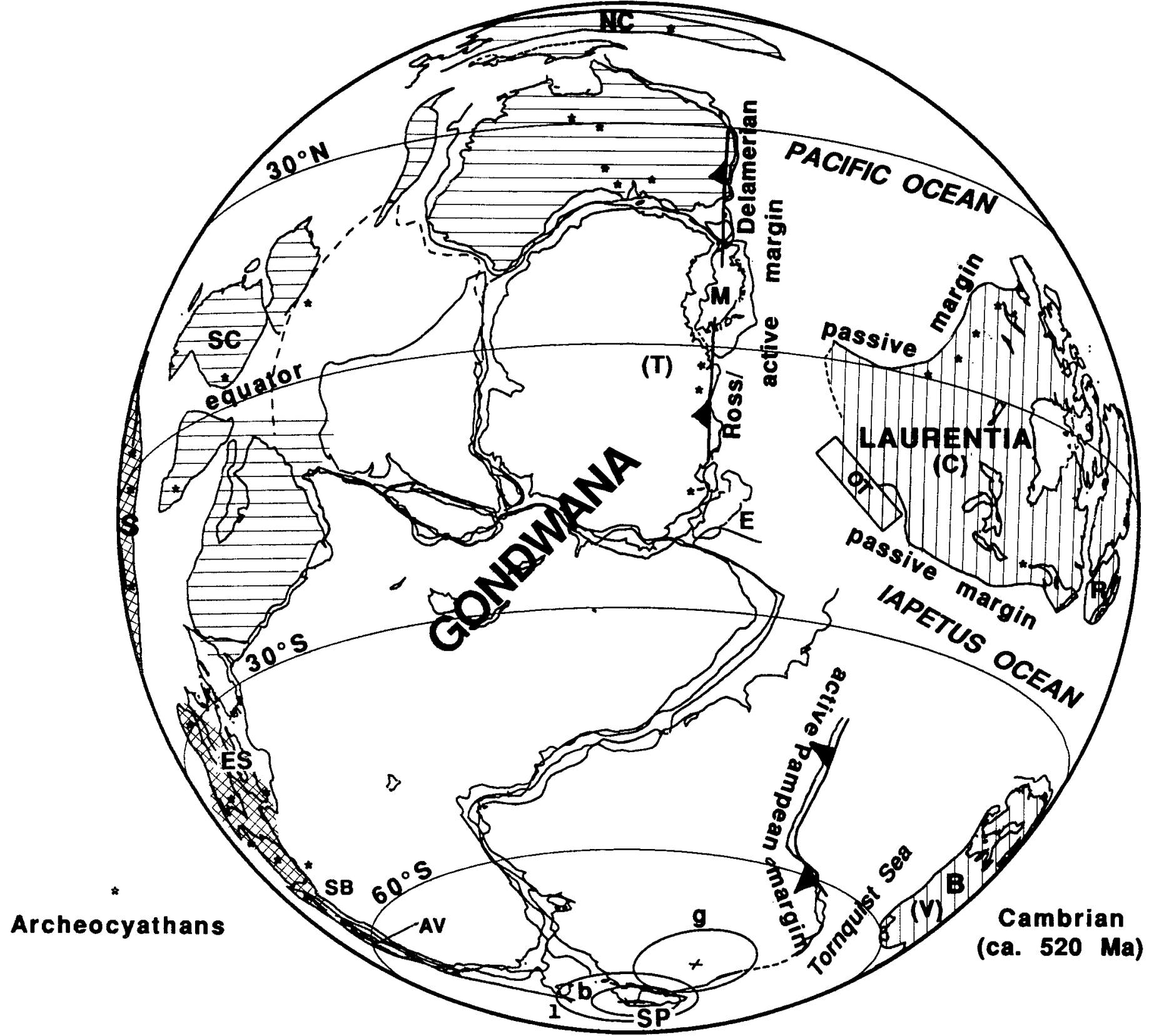

Figure 2. Reconstruction for the mid-Cambrian (ca. $520 \mathrm{Ma}$ ) using the same paleomagnetic poles for Laurentia, Gondwana, and Baltica as McKerrow and others (1992), namely those of Kirschvink (1978) for Gondwana, Tanczyk and others (1987) for Laurentia, and Torsvik and Trench (1991; actually for Arenig-Lllanvirn time) for Baltica. The pole for Laurentia is used as the South Pole. The circles of confidence are at the $95 \%$ level (b, Baltica; $g$, Gondwana; 1 , Laurentia).

V, C, and T are locations of Viking, Columbia, and Tollchuticook trilobite provinces of Jell (1974). Vertical lines are olenellid trilobite realm; horizontal lines are redlichiid trilobite realm; cross-hatching shows intermediate bigotnid trilobite realm (McKerrow and others, 1992). Archecyathan localities are after Courjault-Radé and others, 1992; and McKerrow and others, 1992); note that the extension of these localities to latitudes beyond $-35^{\circ}$ is probably due to rotation of Gondwana during the Cambrian. AV, Avalonia; ES, European shelf; NC, North China; OT, Occidentalia terrane of southern South America (including Precordillera terrane or San Juan province) restored to Ouachita embayment of Laurentia as suggested by Dalla Salda and others (1992b); SB, South Britain; SC, South China. Other abbreviations as in Figure 1.

tory (Dalla Salda and others, 1992a, 1992b). Both orogens contain discontinuous belts of rock of oceanic character together with a history of regional dynamothermal metamorphism and emplacement of granitic plutons that culminated in the mid- to Late Ordovician
(Hatcher and others, 1989; Tucker and Robinson, 1990; Dalla Salda and others, 1992a). The Taconic orogen disappears beneath the Mesozoic and Cenozoic sedimentary cover of the Gulf of Mexico coastal plain. The diachronous late Paleozoic (Ouachita-Alleghanian) defor- 
mation continued south and west into the Ouachita Mountains and the Marathon uplift of Texas, but there was no Taconic deformation in the Ouachita embayment (Kay, 1951; Rodgers, 1970; W. A. Thomas and G. W. Viele, in Hatcher and others, 1989). The northern termination of the Ordovician Famatinian belt is obscured by the Andean overprint. It disappears north-northwestward toward the coast in the Arica embayment near the Arequipa massif (Dalla Salda and others, 1992b; their Fig. 3). An intracratonic branch extends between the Arequipa massif and the Amazonian craton proper (perhaps a failed rift arm following the Sunsas and Brazilide orogens, Fig. 1; Dalmayrac and others, 1980; Forsythe and others, 1993; Dalziel, 1993b). Regarding the Taconic-Ocloyic orogen as a formerly continuous mountain belt, Dalla Salda and others (1992b) used the two orogenic terminations as piercing points, to reconstruct eastern North America and western South America for the time of postulated LaurentiaGondwana collision in the Ordovician (Fig. 3). Paleozoic granitic rocks in the Pampean Ranges of Argentina indicate that the Iapetus ocean floor between these two continents was destroyed by subduction beneath the Gondwana craton (Dalla Salda and others, 1992a). The Taconic orogeny in North America clearly involved island-arccontinent collision (Hatcher and others, 1989; Van der Pluijm and others, 1990); however, this and other tectonic complexities could readily have occurred within the context of overall continent-continent convergence as exemplified by the Alpine orogen of the late Mesozoic, Cenozoic, and present day (Dewey and others, 1973). We suggest that the linear belt of Cambrian to lowermost Ordovician subduction-related granitic rocks of the Appalachians that extends along the Piedmont and Blue Ridge from the Delaware River to Alabama (Sinha and others, 1989) may be interpreted as the detached continuation of the pre-collisional Pampean magmatic arc in South America (Fig. 2).

If the Appalachian and proto-Andean margins did reunite in a collisional event during the Ordovician, then a second rift event along these margins must subsequently have separated the Taconic and Ocloyic portions of the proposed mountain system. The Appalachian margin is marked by promontories and embayments widely believed to reflect transform offsets formed during the initial spreading of the Iapetus oceanic lithosphere. The Ouachita embayment is one of the most prominent of these offsets. As discussed above, the timing of rift-drift transition within the Ouachita embayment appears to be younger than that along the Appalachian margin proper. Thomas (1991) interpreted this as the result of a ridge jump within the expanding Iapetus Ocean. Dalla Salda and others (1992b) suggested, however, that a continental fragment from this embayment might have been left behind in South America as the Occidentalia terrane during a post-Taconic/Ocloyic rift event that separated Laurentia and Gondwana along lines of pre-existing weakness that continued from the latest Precambrian to Cambrian Rome-Rough Creek-Reelfoot rift and Oklahoma trough in North America (Ouachita embayment fault system on Fig. 3; see also Fig. 3 of Dalla Salda and others, 1992b). Evidence of a glaciogenic origin for uppermost Ordovician strata overlying the Precordilleran carbonate platform (including resedimented striated and faceted clasts, Peralta and Carter, 1992) suggest that it was part of Gondwana by the Ashgillian. There is additional evidence of glaciation in southern Africa at that time (I. C. Rust, in Hambrey and Harland, 1981), and some paleomagnetic data suggest that Gondwana was at a significantly higher latitude than Laurentia in the Late Ordovician and Silurian (Van der Voo, 1993; his Fig. 8.25). Hence a major ocean basin may have opened between the two continental masses after the proposed Taconic-Ocloyic collision.
The Oaxaca terrane of southern Mexico (Campa and Coney, 1983) has a Grenvillian basement and a lower Paleozoic sedimentary cover containing Tremadocian trilobites which closely resemble those found along the margin of the Gondwana craton in northern Argentina and Bolivia (Robison and Pantajo-Alor, 1968). Paleomagnetic data from the Grenvillian basement of Oaxaca indicate that these rocks cooled ca. $950 \mathrm{Ma}$ in a location relative to the stable Laurentian craton similar to that of present-day Ontario or Quebec (Ballard and others, 1989). Thus part of Mexico may represent a terrane detached from the vicinity of the Arica embayment in the South American margin following the Taconic-Ocloyic collision (Fig. 4). Alternatively, it could have been derived from the Colombian part of the margin during later interaction of Laurentia and South America (Yañez and others, 1991). In either case, like the Precordillera of northwestern Argentina that is also exotic in present-day terms, it may represent an important "tectonic tracer" (Dalziel, 1993a), recording past interaction of the two major continents.

The Acadian orogeny in eastern North America, in addition to involving arc-continent collision (Hatcher and others, 1989), is characterized by a strong component of dextral transpression that appears to have migrated southwestward along the continental margin at least from maritime Canada to Virginia, during the Early Devonian to Early Mississippian (Rodgers, 1970; Hatcher and others, 1989; Ferrill and Thomas, 1988). The "Eo-Hercynian" structures of northern Chile, Bolivia, and Peru, which are obliquely truncated by the present Andean margin, may reflect the counterpart of the Acadian event in South America. Dalmayrac and others (1980) postulated the presence of a "southeast Pacific continent" as a source of sediment outboard of the Arequipa massif in the mid-Paleozoic. We therefore suggest that the Acadian orogeny that followed the post-Taconic/Ocloyic separation of Laurentia and Gondwana may in part reflect dextral transpressional collision between the two continental masses (Fig. 4; see also reconstruction of Kent and Van der Voo, 1990; Van der Voo, 1993). Bahlburg (1993) notes the mingling of cold-water (Malvinokaffric) and warm-water (Appalachian) faunas in the Emsian to Eifelian strata of northern Chile (Isaacson and Sablock, 1989; see Fig. 3) that are part of a mid- to upper Paleozoic passive-margin sequence that, he suggests, may have developed following post-Taconic/Ocloyic separation of Laurentia and Gondwana.

The precise path taken by Laurentia relative to Gondwana in the Paleozoic Era remains to be determined, but a significant ocean basin could have opened between the two in late Paleozoic time following the proposed Acadian collision (Van der Voo, 1993, his Fig. 8.5). The history of strike-slip basins along the eastern seaboard (Gates and others, 1986) indicates the importance of right-lateral oblique displacements in late Paleozoic time during final closure of Laurentia with northwest Africa in the terminating Ouachita-Alleghanian collision that completed the amalgamation of Pangea (Ziegler, 1989).

\section{IMPLICATIONS OF A COMPLEX WILSON CYCLE}

In one of the first papers applying plate-tectonic principles to problems of orogenesis, Dewey (1969) suggested that an ocean like the Atlantic Ocean is destined to develop at least one Andean-type ocean-continent convergent boundary, and eventually close to a Mediterranean-type basin during continent-continent collision: the socalled "Wilson cycle." The proposed clockwise motion of the North American continent from a position adjacent to the proto-Andean margin of Gondwana in late Neoproterozoic time, around South America to complete the amalgamation of Pangea by collision with 


\section{PALEOZOIC LAURENTIA-GONDWANA INTERACTION}

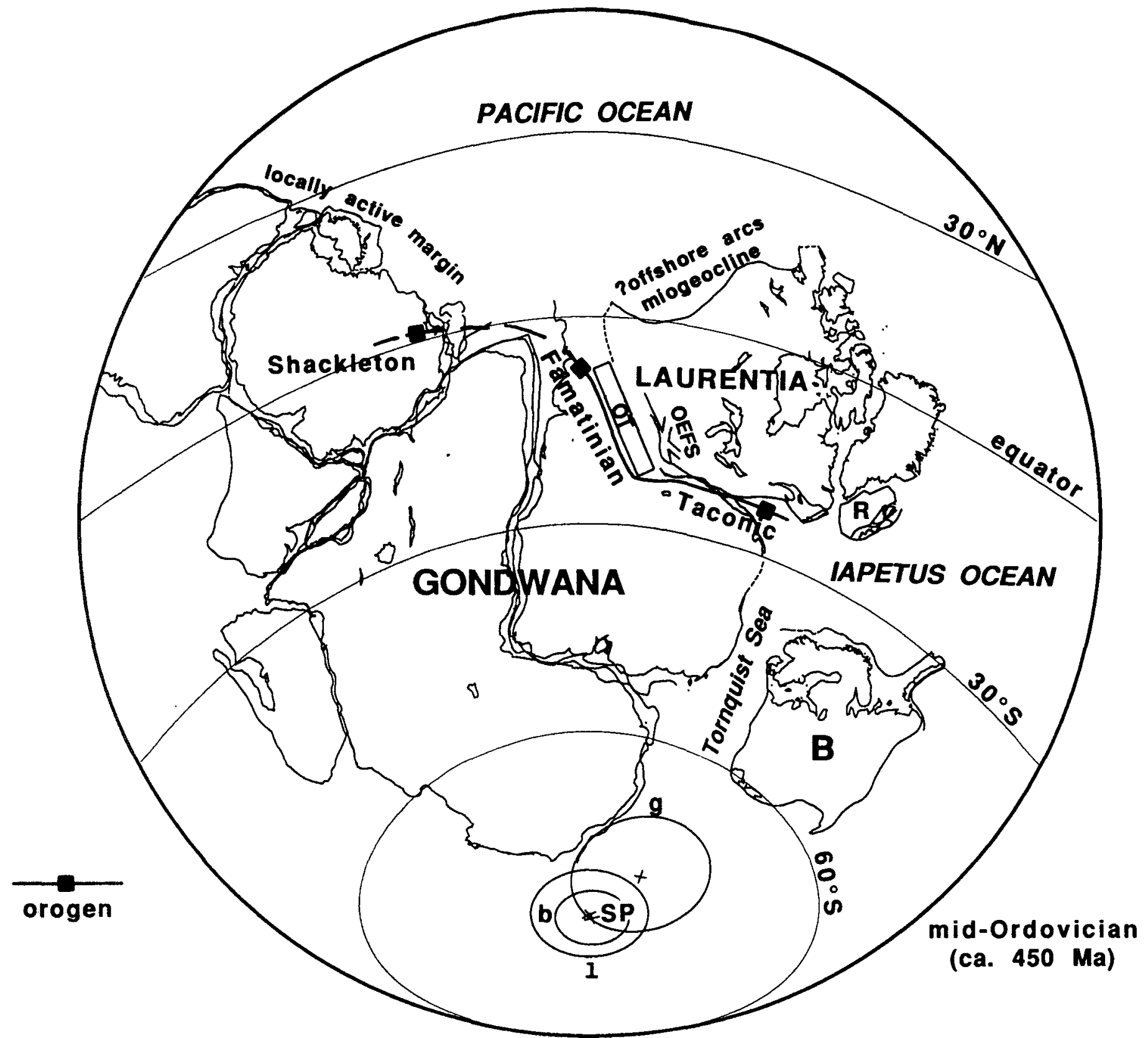

Figure 3. Reconstruction for the time of the Taconic, Ocloyic, and Shackleton orogenies during the mid-Ordovician using the composite poles of Van der Voo (1993, Table 8-1) for Laurentia and Gondwana (northwest Africa). Baltic is retained in the position shown in Figure 2 as no poles are available for this interval. Circles of confidence are at the $95 \%$ level, and labeling is as in Figure 2. OEFS, Ouachita embayment fault system (see text). Other abbreviations as in Figures 1 and 2.

northwestern Africa in the late Paleozoic, demonstrates the potential complexity of the cycle of ocean-basin development and destruction that seems inevitable in a dynamic globe of constant size (Duncan and others, 1992). If correct, this relative motion embodies the worst fears of both tectonicists and paleomagnetists, a net displacement of $\sim 10,000 \mathrm{~km}$ that was subparallel to the Appalachian-Andean orogenic system and involved considerable change in paleolongitude (Figs. 1-4). Yet the hypothesis does appear to be one way to explain the long-recognized interweaving of the Caledonian, Hercynian, and Appalachian mountain belts within early Mesozoic Pangea, as well as the diachronous initiation of subduction of Pacific Ocean lithosphere along the proto-Andean margin of South America. Bailey (1935) noted how the Appalachian belt "steps clear of its Caledonian predecessor" as the orogen is traced southward. The model proposed here explains this relationship by suggesting that the final Alleghanian collision with northwestern Africa was superposed both on the Caledonian belt that resulted primarily from Laurentia-Baltica/southern Britain collision, and on the Taconic and Acadian belts that may both have involved Laurentia-South America collision. The motion of Laurentia around South America following the development of Gondwanan Iapetus in 


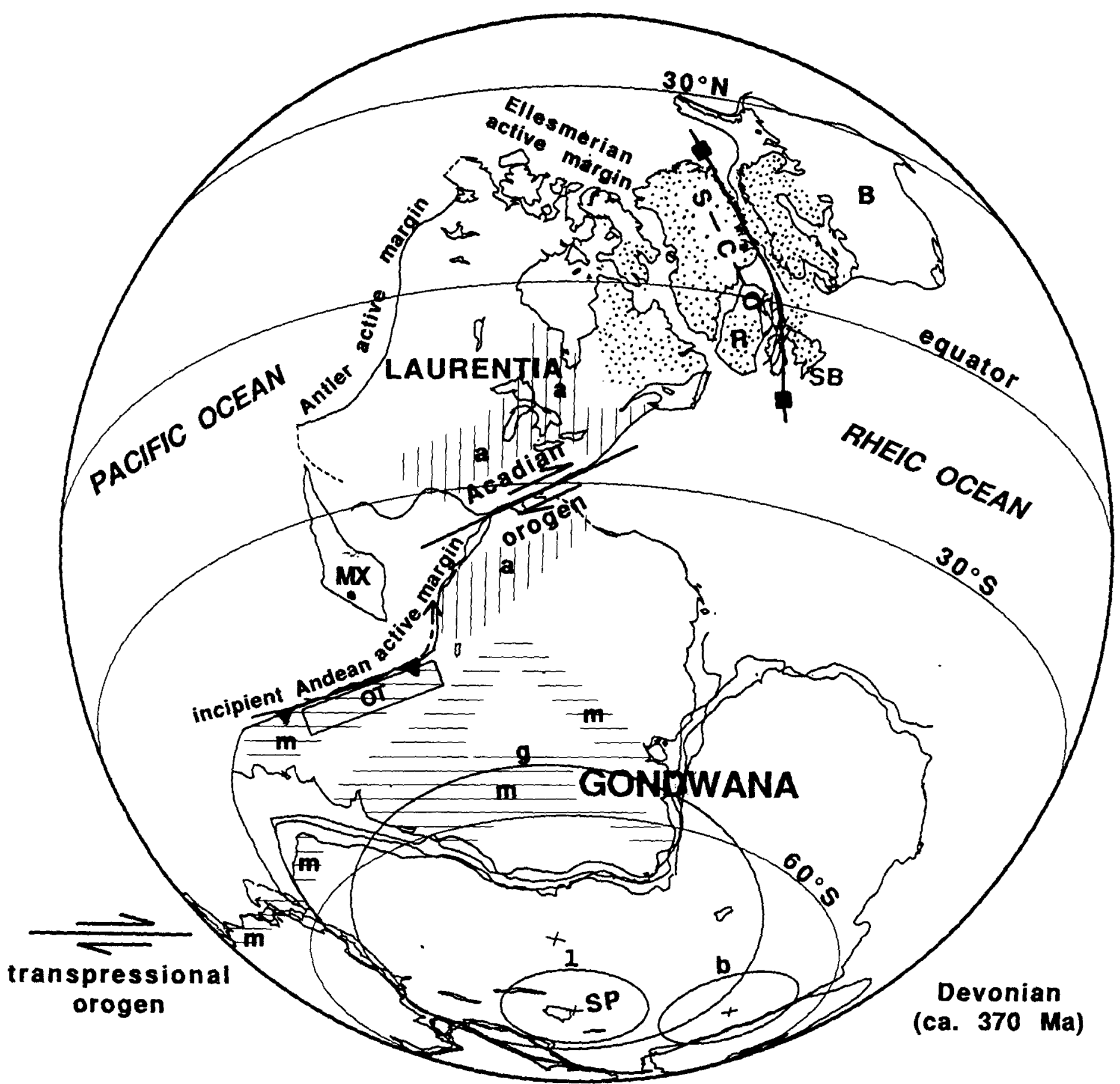

Figure 4. Reconstruction for Laurentia-Baltica (following the Scandian-Caledonian orogeny) and Gondwana during later stages of the Acadian orogeny using the composite poles of Van der Voo (1993, Table 8-1). The small circles are the circles of confidence at the 95\% level labeled as in Figure 2. Note that the poles for Baltica and Laurentia do not quite agree despite the fact that the two continents were positioned using the Mesozoic-Cenozoic sea-floor-spreading data (Lawver and others, 1990).

MX, Mexico (in present position with respect to Laurentia, the black dot represents location of Oaxaca block); S-C-O, Scandian-Caledonian orogen. Other abbreviations as in Figures 1-3. Letters a (vertical lines) and m (horizontal lines) represent Emsian distribution of Appalachian and Malvinokaffric faunas, respectively (Johnson and Boucot, 1973); stippling represents the "Old Red Continent." 


\section{PALEOZOIC LAURENTIA-GONDWANA INTERACTION}

latest Neoproterozoic to Cambrian time appears to have been similar to the interaction between Africa and Europe during their Mesozoic and Cenozoic drift eastward relative to the Americas (Dewey and others, 1973). The minimum rates of plate motion required are well within the range measured during Mesozoic and Cenozoic time (Meert and others, 1993). Subduction of lithosphere of the Pacific Ocean basin beneath the proto-Andean margin could not begin until Laurentia had moved out of the way. The earliest subduction-related metamorphism documented in the Andean coastal cordillera of Central Chile is early late Carboniferous (Hervé and others, 1981). Subduction in northern Chile did not start until the latest Carboniferous (Bahlburg, 1993; see Fig. 4).

The final Alleghanian collision of Laurentia with northwestern Africa appears to have had profound consequences for the development of the cratonic interior of the North American continent. It transmitted compressive stress more than $1,000 \mathrm{~km}$ into the craton (Craddock and Van der Pluijm, 1989) and influenced Absaroka-sequence sedimentation during the Carboniferous (Sloss, 1988). There is a striking coincidence in time of the erosional surfaces representing the Sauk-Tippecanoe and Tippecanoe-Kaskaskia sequence boundaries on the Laurentian craton (Sloss, 1988), and of the Alpha-Beta and Beta-Gamma sequence boundaries of the Transamazonian craton cover (Soares and Landim, 1978), with the earlier Taconic and Acadian collisions of Laurentia and Gondwana postulated here. Subsidence events in interior North America have recently been correlated with phases of the Appalachian orogeny (Beaumont and others, 1988; Howell and Van der Pluijm, 1990). We suggest that three LaurentiaGondwana collisions during the Paleozoic Era may have resulted in intraplate stresses of sufficient magnitude to cause virtually simultaneous uplift of arches and downwarp of basins throughout both cratons. The sequence stratigraphy of the Russian platform may also be explained in this way, at least for the Acadian and Alleghanian collisions when there was structural continuity between all three cratons (Fig. 4). Thus there may have been a close link between epeirogeny and collisional orogenesis on a near-global scale throughout the Paleozoic.

\section{ACKNOWLEDGMENTS}

We are grateful to Douglas Rankin and Rob Van der Voo, for constructive reviews of the manuscript; to Robert Hatcher, Jr. and William Thomas for helpful discussions; and to Art Sylvester, and J. Wright Horton, Jr. for their editorial assistance. We thank Allison "Pete" Palmer for drawing to our attention the potentially critical contribution by Peralta and Carter regarding the Argentine Precordillera as well as the important Tremodacian strata at Oaxaca, Mexico. The reconstructions were made using PLATES software of the Institute for Geophysics, University of Texas at Austin. Funds from the following grants were used in field work and/or the preparation of the manuscript: National Science Foundation Grants EAR 90-05495 and DPP 89-16436 to Dalziel, and CONICET 300220088 to Dalla Salda.

\section{REFERENCES CTTED}

Abbruzzi, J., Kay, S. M., and Bickford, M. E., 1993, Implications for the nature of the Precordilleran basement from Precambrian xenoliths in Miocene volcanic rocks, San Juan Province, Argentina XII Congreso Geologico Argentino, Mendoza, Tomo III, p. 331-339.

Aceñolaza, F. G., and Durand, F. R., 1986, Upper Precambrian-Lower Cambrian biota from the northwest of Argentina: Geological Magazine, v. 124, p. 367-375.

Bahlburg, H., 1993, The hypothetical Pacific continent revisited: New evidence from the mid-Paleozoic basins of northern Chile: Geology, v. 21, p. 909-912.

Bailey, E. B., 1935, Tectonic essays, mainly alpine: Oxford, U.K., Clarendon Press, 200 p.
Ballard, M. M., Van der Voo, R., and Urrutia-Fucugauchi, J., 1989, Paleomagnetic results from Grenvillian-aged rocks from Oaxaca, Mexico: Evidence for a displaced terrane: Precambrian Research, v. 42 , p. 343-352.

Beaumont, C., Quinlan, G., and Hamilton, J., 1988, Orogeny and stratigraphy: Numerical models in the eastern interior of North America: Tectonics, v. 7, p. 389-416.

Bell, R., and Jefferson, C. W., 1987, An hypothesis for an Australia-Canadian connection in the late Paleozoic and the birth of the Pacific Ocean: PacRim Congress 1987, Parkville, Australia 3950.

Bird, J. M., and Dewey, J. F., 1970, Lithosphere plate-continental margin tectonics and the evolution of the Appalachian orogen: Geological Society of America Bulletin, v. 81, p. 1031-1060.

Bond, G. C., Nickeson, P. A., and Kominz, M. A., 1984, Breakup of a supercontinent between $625 \mathrm{Ma}$ and 555 Ma: New evidence and implications for continental histories: Earth and Planetary Science Letters, v. 70, p. 325-345.

Bond, G., Kominz, M., and Devlin, W., 1991, Rapid global-scale events during the Precambrian-Cambrian transition: Consequence of rapid dispersal of a late Proterozoic supercontinent?: Geological Society of America Abstracts with Programs, p. A112.

Bordonaro, O. L., 1990, El sistema Cambrico de la Provincia de San Juan: XI Congreso Geologico Argentino, San Juan, p. 18-30.

Argentino, San Juan, p. 18-30.
Borrello, A. V., 1971, The Cambrian of South America, in Holland, C. H., ed., Cambrian of the New World, p. 385-438.

Campa, M. F., and Coney, P. J., 1983, Tectonostratigraphic terranes and mineral resource distribution in Mexico: Canadian Journal of Earth Sciences, v. 20, p. 1040-1051.

in Mexico: Canadian Journal of Earth Sciences, v. 20, p. 1040-1051.
Courjault-Radé, P., Debrenne, F., and Gandin, A., 1992, Paleogeographic and geodynamic evolution of the Gondwana margins during the Cambrian: Terra Nova, v. 4, p. 657-667.

Craddock, J. P., and van der Plujim, B. A., 1989, Late Paleozoic deformation of the cratonic carbonate cover of eastern North America: Geology, v. 17, p. 416-419.
.

Craig, G. Y., ed., 1991, The geology of Scotland (3rd edition): London, U.K., The Geological Society,

612 p.
Dalla Salda, L. H., Cingolani, C. A., and Varela, R., 1992a, Early Paleozoic orogenic belt of the Andes in southwestern South America: Result of Laurentia-Gondwana collision?: Geology, v. 20, p. $616-620$.

Dalla Salda, L. H., Dalziel, I.W.D., Cingolani, C. A., and Varela, R., 1992b, Did the Taconic Appalachians continue into South America?: Geology, v. 20, p. 1059-1062.

Dalmayrac, B., Lancelot, J. R., and Leyreloup, A., 1977, Two-billion-year granulites in the late Precambrian metamorphic basement along the southern Peruvian coast: Science, v. 198, p. 49-51 ene d'amerique du sud, structure et evolucion d'un orogene intracratonique: Geologische Rund-
enne

schau, v. 69, p. 1-21.
Dalziel, I.W.D., 1991, Pacific margins of Laurentia and East Antarctica-Australia as a conjugate rift pair: Evidence and implications for an Eocambrian supercontinent: Geology, v. 19, p. 598-601.

Evidence and implications for an Eocambrian supercontinent: Geology, v. 19, p. 598-601.
Dalziel, I.W.D., 1992a, On the organization of American plates in the Neoproterozoic and the breakout of Laurentia: GSA Today, v. 2, p. 237-241.

of Laurentia: GSA Today, v. 2, p. 237-241.
Dalziel, I.W.D., 1992b, Antarctica: A tale of two supercontinents?: Annual Reviews of Earth and Planetary Science, v. 20, p. 501-526.

etary Science, v. 20, p. 501-526.
Dalziel, I.W.D., 1993a, Tectonic tracers and the origin of the proto-Andean margin: XII Congreso Geologico Argentino, Mendoza, Tomo III, p. 367-374.

Geologico Argentino, Mendoza, Tomo III, p. 367-374.
Dalziel, I.W.D., 1993b, Precambrian Scotland as a I Laurentia-Gondwana link and the role of cratonic

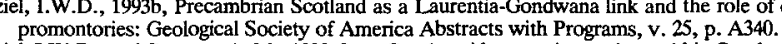

Dalziel, I.W.D., and Grunow, A. M., 1992, Late Gondwanide tectonic rotations within Gondwanaland: Tectonics, v. 11 , p. 603-606.

Dengo, G., 1985, Mid America: Tectonic setting for the Pacific margin from southern Mexico to northwestern Colombia, in Nairn, A.E.M., Stehli, F. G., and Uyeda, S., eds., The ocean basins and margins; The Pacific Ocean, Volume 7A: New York and London, Plenum Press, p. 123-180.

Dewey, J. F., 1969, Continental margins; a model for the conversion of Atlantic type to Andean type: Earth and Planetary Science Letters, v. 6, p. 189-197.

Dewey, J. F., Pitman, W. C., III, Ryan, W.B.F., and Bonnin, J., 1973, Plate tectonics and the evolution of the Alpine system: Geological Society of America Bulletin, v. 81, p. 683-692.

Duncan, C. C., Hauck, M. L., and Turcotte, D. L., 1992, On the breakup and coalescence of continents: Eos (American Geophysical Union Spring Supplement), p. 74.

Eisbacher, G. H., 1985, Late Proterozoic rifting, glacial sedimentation, and sedimentary cycles in the light of Windermere deposition, westem Canada: Palaeogeography, Palaeoclimatology, Palaeoecology, v. 51, p. 231-254.

Ferrill, B. A., and Thomas, W. A., 1988, Acadian dextral transpression and synorogenic sedimentary successions in the Appalachians: Geology, v. 16, p. 604-608.

Forsythe, R. D., Davidson, J., Mpodozis, C., and Jesinkey, C., 1993, Lower Pateozoic relative motion of the Arequipa block and Gondwana; Paleomagnetic evidence from Sierra de Almeida of northern Chile: Tectonics, v. 12, p. 219-255.

Gates, A. E., Simpson, C., and Glover, L., III, 1986, Appalachian Carboniferous dextral strike-slip faults: An example from Bookneal, Virginia: Tectonics, v. 5, p. 112-133.

Gower, C. F., Rivers, T., and Ryan, B., eds., 1990, Mid-Proterozoic Laurentia-Baltica: Geological Association of Canada Special Paper 38, $581 \mathrm{p}$.

Grunow, A. M., 1993, New paleomagnetic data from Antarctica: Implications for Early Paleozoic paleogeographic reconstructions and Gondwana apparent polar wander paths: Geological Society of America Abstracts with Programs, v. 25, p. A231.

Hambrey, M. J., and Harland, W. B., 1981, Earth's pre-Pleistocene glacial record: Cambridge, U.K., Cambridge University Press, $1,004 \mathrm{p}$.

Harland, W. B., and Gayer, R. A., 1972, The Arctic Caledonides and earlier oceans: Geological Magazine, v. 109 , p. $289-314$.

Hartnady, C.J.H., 1986, Was North America ('Laurentia') part of south-western Gondwanaland during the late Proterozoic era?: South African Journal of Science, v. 82, p. 251-254.

Hatcher, R. D., Jr., 1989, Tectonic synthesis of the U.S. Appalachians, in Hatcher, R. D., Jr., and others, eds., 1989, The geology of North America, Volume F-2, The Appalachian-Ouachita orogen in the United States: Boulder, Colorado, Geological Society of America, p. 511-535.

Hatcher, R. D., Jr., Thomas, W. A., and Viele, G. W., 1989, The geology of North America, Volume F-2: The Appalachian-Ouachita orogen in the United States: Boulder, Colorado, Geological Society of America, $767 \mathrm{p}$.

Heaman, L. M., LeCheminant, A. N., and Rainbird, R. H., 1992, Nature and timing of Franklin igneous events, Canada: Implications for a Late Proterozoic mantle plume and the break-up of Laurentia: Earth and Planetary Science Letters, v. 109, p. 117-131

Hervé, F., Davidson, J., Godoy, E., Mpodozis, C., and Covacevich, V., 1981, The late Paleozoic in Chile: Stratigraphy, structure and possible tectonic framework: Anais Academía Brasileira de Ciencias, v. 53, p. 361-373.

Hoffman, P. F., 1989, Precambrian geology and tectonic history of North America, in Bally, A. W., and Palmer, A. R., eds., The geology of North America-An overview, Volume A, p. 447-512.

Hoffman, P. F., 1991, Did the breakout of Laurentia turn Gondwanaland inside out?: Science, v. 252, p. $1409-1412$.

Hoffman, P. F., 1992, Relative timing of Rodinia breakup and Gondwanaland assembly: Critical test of Laurentiacentric models for the Neoproterozoic supercontinent: Eos (American Geophysical Union Spring Supplement), p. 115

Howell, P. D., and van der Pluijm, B. A., 1990, Early history of the Michigan basin; subsidence and Appalachian tectonics: Geology, v. 18, p. 1195-1198.

Asaacson, P. E., and Sablock, P. E., 1989, Devonian system in Bolivia, Peru, and northern Chile, in
Istal 


\section{DALZIEL AND OTHERS}

McMillan, N. J., Embry, A. F., and Glass, D. J., eds., Devonian of the world: Canadian Society of Petroleum Geologists Memoir 14, p. 719-728.

Jell, P. A., 1974, Faunal provinces and possible planetary reconstruction of the Middle Cambrian: Journal of Geology, v. 82, p. 319-350.

Jezek, P., Willner, A. P., Aceñolaza, F. G., and Miller, H., 1985, The Puncoviscana trough-A large basin of late Precambrian to Early Cambrian age on the Pacific edge of the Brazilian shield: Geologische Rundschau, v. 74, p. 573-584.

Johnson, J. G., and Boucot, A. J., 1993, Devonian brachiopods, in Hallam, A., ed., Atlas of paleobiogeography: Amsterdam, The Netherlands, Elsevier, p. 89-98.

Kamo, S. L., Gower, C. F., and Krogh, T. E., 1989, Birthdate for the Iapetus Ocean? A precise U-Pb zircon and baddelyite age for the Long Range dikes, southeast Labrador: Geology, v. 17 p. $602-605$.

Kay, M., 1951, North American geosynclines: The Geological Society of America Memoir 48, 143 p. ent, D. V., and Van der Voo, R., 1990, Palaeozoic palaeogeography from palaeomagnetism of the Atlantic-bordering continents, in McKerrow, W. S., and Scotese, C. R., eds., Palaeozoic palaeogeography and biogeography: Geological Society of London Memoir 12, p. 49-56.

Keppie, J. D., 1991, Avalon, an exotic Appalachian-Caledonide terrane of western South American provenance:

Kirschvink, J. L., 1978, The Precambrian-Cambrian boundary problem; paleomagnetic directions from the Amadeus Basin, Central Australia: Earth and Planetary Science Letters, vo 40, p. 91-100.

Klitgord, K D., and Schouten, H., 1986, Plate kinematics of the central Atlantic, in Vogt, P. R., and Tucholke, B. E., eds., The westem North Atlantic region: Geology of North America, Volume M: Boulder, Colorado, Geological Society of America, p. 351-378.

Laubacher, G., and Mégard, F., 1985, The Hercynian basement: A review, in Pitcher, W. S., Atherton, M. P., Cobbing, E. J., and Beckinsale, R. D., eds., Magmatism at a plate edge: Błackie, Glasgow and London, p. 29-35.

Lawver, L. A., Müller, R. D., Srivastava, S. P., and Roest, W. R., 1990, The opening of the Arctic, in Bleil, U., and Thiede, J., Arctic versus Antarctic geology, NATO ASI Series, ser. C, v. 308: Amsterdam, The Nethertands, Kluwer Academic Publishers, p. 29-62

Litherland, M., Annells, R. N., Darbyshire, D.P.F., Fletcher, C.J.N., Hawkins, M. P., Klinck, B. A., Mitchell, W. I., O'Conner, E. A., Pitfield, P.E.J., Power, G, and Webb, B. C., 1989, The Proterozoic of eastern Bolivia and its relationship to the Andean mobile belt: Precambrian Research, v. 43 , p. $157-174$

Loske, W., 1992, The west-Argentinian Precordillera: A lower Paleozoic back-arc basin? [abs.], in Guttierrez, Marco J., and others, eds., Paleozoico Inferior de Ibero America, Universidad de Extremadura, Mérida, and $96-97$.

Lowe, D. R. 1985, Ouachita Trough: Part of a Cambrian failed rift system: Geology, v. 13, p. 790-793. McKerrow, W. S., Dewey, J. F., and Scotese, C. R., 1991, The Ordovician and Silurian development of the lapetus Ocean: London, U.K., Palacontological Society, Special Papers in Palaeontology No. 44, p. 165-178.

McKerrow, W. S., Scotese, C. R., and Brasier, M. D., 1992, Early Cambrian continental reconstructions: Geological Society of London Journal, v. 149, p. 599-606.

McMenamin, M.A.S., and McMenamin, D.L.S., 1990, The emergence of the animals-The Cambrian breakthrough: New York, Columbia University Press, $217 \mathrm{p}$.

Meert, J. G., Van der Voo, R., Powell, C. M., Li, Z., McElhinny, M. W., Chen, Z., and Symonds,

D.T.A., 1993, A plate-tectonic speed limit?: Nature, v. 363, p. 216-217.
Mon, R., and Hongn, F., 1991, The structure of the Precambrian and lower Paleozoic basement of the Central Andes between $22^{\circ}$ and $32^{\circ}$ S. Lat.: Geologische Rundschau, v. 80, p. 745-758.

Moores, E. M., 1991, Southwest U.S.-East Antarctic (SWEAT) connection: A hypothesis: Geology, v. 19, p. $425-428$.

Peach, B. N., Horne, J., Gunn, W., Clough, C. T., Hinxman, L. W., and Teall, J.J.H., 1907, The geological structure of the northwest Highlands of Scotland: Geological Survey Memoir, U.K.

Peralta, S. H., and Carter, C. H., 1992, Late Ordovician Gondwana glaciation: Evidence in pebbly mudstones of the Precordillera, province of San Juan, Argentina: Geological Society of America Abstracts with Programs, v. 24, p. A91

Powell, C. McA., Li, Z. X., McElhinny, M. W., Meert, J. G., and Park, J. K., 1993, Paleomagnetic constraints on timing of the Neoproterozoic breakup of Rodinia and the Cambrian formation of Gondwana: Geology, v. 21, p. 889-892.

Ramos, V. A., Jordan, T. E., Allmendinger, R. W., Mpodozis, C., Kay, S. M., Cortés, J. M., and Palma, M. A., 1986, Paleozoic terranes of the central Argentine-Chilean Andes: Tectonics, v. 5 , p. $855-880$.

Rankin, D. W., Furnes, H., Bishop, A. C., Cabanic, B., Milton, D. J., O'Brien, S. J., and Thorpe, R. S., 1988, Plutonism and volcanism related to the pre-Arenig evolution of the Caledonide-Appalachian orogen, in Harris, A. L., and Fettes, D. J., The Caledonian-Appalachian Orogen: Geological Society of London Special Publication No. 38, p. 149-183

Robison, R. A., and Pantajo-Alor, J., 1968, Tremadocian trilobites from the Nochixtlan region, Oaxaca, Mexico: Journal of Paleoentology, v. 42, p. 767-800.

Rodgers, J., 1970, The tectonics of the Appalachians: New York, Wiley Interscience, 271 p.

Ross, R. J., 1975, Early Paleozoic trilobites, sedimentary facies, lithospheric plates, and ocean currents: Fossils strata, v. 4, p. 307-329.

Scotese, C. R., and McKerrow, W. S., 1990, Revised world maps and introduction, in McKerrow, W. S., and Scotese, C. R., eds., Palaeozoic palaeogeography and biogeography: Geological Society of London Memoir 12, p. 1-21.
Sears, J. W., and Price, R. A., 1978, The Siberian connection: A case for Precambrian separation of the North American and Siberian cratons: Geology, v, 6, p. 267-270.

Secor, D. T., Samson, S. L., and Snoke, A. W., 1983, Confirmation of the Carolina Slate Belt as an exotic terrane: Science, v. 221, p. 649-651.

Shackleton, R. M., Ries, A.C., Coward, M. P., and Cobbold, P. R., 1979, Structure, metamorphism and geochronology of the Arequipa Massif of coastal Peru: Geological Society of London Journal, v. 136, p. $195-214$.

Shergold, J. H., and Webers, G. F., 1992, Late Dresbachian (Idamean) and other trilobite faunas from the Heritage Range, Ellsworth Mountains, West Antarctica, in Webers, G. F., and others, eds., Geology and paleontology of the Ellsworth Mountains, West Antarctica: Geological Society of America Memoir 170, p. 125-168.

Sinha, A. K., Hund, E. A., and Hoggan, J. P., 1989, Paleozoic accretionary history of the North American plate margin (central and southern Appalachians), in Hitlhouse, J. W., ed., Deep structure and past kinematics of accreted terranes: Washington, D.C., American Geophysical Union Geophysical Monograph Series, Volume 50, p. 219-238.

Sloss, L. L., 1988, Conclusions, in Sloss, L. L., ed., Sedimentary cover-North American Craton: U.S. Boulder, Colorado, Geological Society of America, p. 493-496.

Soares, P. C., and Landim, P.M.B., 1978, Tectonic cycles and sedimentary sequences in the Brazilian intracratonic basins: Geological Society of America Bulletin, v. 89, p. 181-191.

Symons, D.T.A., and Chiasson, A. D., 1990 , Paleomagnetism of the Callander complex and the Cambrian apparent polar wander path for North America: Canadian Journal of Earth Sciences, v. 28, p. $355-363$

Tanczyk, E. I., Lapointe, P., Morris, W. A., and Schmidt, P. W., 1987, A paleomagnetic study of the layered mafic intrusion at Sept-Iles, Quebec: Canadian Journal of Earth Sciences, v. 24, p. $1431-1438$

Thomas, W. A., 1991, The Appalachian-Ouachita rifted margins of southeastem North America: Geological Society of America Bulletin, v. 103, p. 415-431.

Torsvik, T. H., Olesen, O., Ryan, P. D., and Trench, A., 1990, On the palaeogeography of Baltica during the Palaeozoic: New palaeomagnetic data from the Scandinavian Caledonides: Geophysical Jourthe Palaeozoic: New palaeomagnetic

Torsvik, T. H., and Trench, A., 1991, The Lower-Middle Ordovician paleofield of Scandinavia: Southern Sweden "revisited": Physics of the Earth and Planetary Interiors, v. 65, p. 283-291.

Tucker, R., and Robinson, P., 1990, Age and setting of the Bronson Hill magmatic arc: A re-evaluation based on U-Pb zircon ages in southem New England: Geological Society of America Bulletin, v. 102 , p. $1404-1419$.

Van der Pluijm, B. A., Johnson, R. J.E Van der Voo, R., 1990, Early Paleozoic paleogeography and accretionary history of the Newfoundland Appalachians: Geology, v. 18, p. 898-901.

Van der Vo, R., 1993, Paleomagnetism of the Atlantic, Tethys, and Iapetus Oceans: Cambridge, U.K. Cambridge University Press, $411 \mathrm{p}$.

Wasteneys, H A Clark A H J in the Arequipa massif of southern Peru: Grenvillian, not Early Proterozoic in age: Geological Association of Canada/Mineralogical Association of Canada, Program and Abstracts, p. A109.

Webers, G. F., and Yochelson, E. L., 1989, Late Cambrian molluscan faunas and the origin of the Cephalopoda, in Crame, J. A., ed., Origins and evolution of the Antarctic biota: Geological Cephalopoda, in Crame, J. A., ed., Origins and evolution

Webers, G.F. Pojeta, J., and Yochelson, E. L. 1992, Ca 29. Ellsworth Mountains, West Antarctica, in Webers, G. F., and others, eds., Geology and paleontology of the Ellsworth Mountains, West Antarctica: Geological Society of America Memoir 170 , p. 181-248.

Williams, $\mathrm{H}$., 1964, The Appalachians in northeastern Newfoundland-A two-sided symmetrical system: American Journal of Science, v. 262, p. 1137-1158.

Williams, H., and Hiscott, R. N., 1987, Definition of the Iapetus rift-drift transition in western Newfoundland: Geology, v. 15, p. 1044-1047.

Wilson, J. T., 1966, Did the Atlantic close and then re-open?: Nature, v. 211, p. 676-681

Yanez, P., Ruiz, J., Patchett, P. J., Ortega-Gutierrez, F., and Gehrels, G. E., 1991, Isotopic studies of the Acatlan Complex, southern Mexico: Implications for Paleozoic North American tectonics: Geological Society of America Bulletin, v. 103, p. 817-828.

Ye, H., and Soegaard, K., 1993, Van Hom Sandstone and Paleozoic miogeocline, in Soegaard, K. Neilsen, K. C., Marsaglia, K., and Barnes, C., Precambrian geology of Franklin Mountains and Van Horn area, Trans-Pecos Texas, Field Trip Guide: Geological Society of America, SouthCentral Section, Dallas, Texas, p. 63-72.

Ziegler, P. A., 1989, Evolution of Laurussia: Dordecht, The Netherlands, Kluwer, 102 p.

MANUSCRIPT RECEIVED BY THE SOCIETY DECEMBER 8, 1992

REVISED MANUSCRIPT RECEIVED JUNE 4, 1993

MANUSCRIPT ACCEPTED JUNE 9, 1993

CONTRIBUTION TO IGCP PROGRAMS 345, 279, AND 288

INSTTTUTE FOR GEOPHYSICS CONTRIBUTION NO. 939 